\title{
How Surface Properties of Silica Nanoparticles Influence Structural, Microstructural and Biological Properties of Polymer Nanocomposites
}

\author{
Łukasz Zych ${ }^{1}$, Anna Maria Osyczka ${ }^{2}$, Agnieszka Łacz $^{3}{ }^{3}$ Agnieszka Różycka $^{4}{ }^{4}$ Wiktor Niemiec ${ }^{5}$, \\ Alicja Rapacz-Kmita ${ }^{1}$, Ewa Dzierzkowska ${ }^{6}$ and Ewa Stodolak-Zych ${ }^{6, * \mathbb{D}}$ \\ 1 Department of Ceramics and Refractories, AGH University of Science and Technology, \\ 30-059 Krakow, Poland; lzych@agh.edu.pl (Ł.Z.); kmita@agh.edu.pl (A.R.-K.) \\ 2 Department of Cell Biology and Imaging, Institute of Zoology and Biomedical Research, \\ Jagiellonian University, 30-387 Krakow, Poland; a.m.osyczka@uj.edu.pl \\ 3 Department of Inorganic Chemistry, AGH University of Science and Technology, 30-059 Krakow, Poland; \\ alacz@agh.edu.pl \\ 4 Department of Building Materials Technology, AGH University of Science and Technology, \\ 30-059 Krakow, Poland; ar@agh.edu.pl \\ 5 Department of Silicates and Macromolecular Compounds, AGH University of Science and Technology, \\ 30-059 Krakow, Poland; wniemiec@agh.edu.pl \\ 6 Department of Biomaterials and Composites, AGH University of Science and Technology, \\ 30-059 Krakow, Poland; dzierzkowska@agh.edu.pl \\ * Correspondence: stodolak@agh.edu.pl
}

check for updates

Citation: Zych, Ł.; Osyczka, A.M.; Łacz, A.; Różycka, A.; Niemiec, W.; Rapacz-Kmita, A.; Dzierzkowska, E.; Stodolak-Zych, E. How Surface Properties of Silica Nanoparticles Influence Structural, Microstructural and Biological Properties of Polymer Nanocomposites. Materials 2021, 14, 843. https://doi.org/10.3390/ ma14040843

Academic Editor: Federico Carosio

Received: 1 December 2020

Accepted: 4 February 2021

Published: 10 February 2021

Publisher's Note: MDPI stays neutral with regard to jurisdictional claims in published maps and institutional affiliations.

Copyright: (c) 2021 by the authors. Licensee MDPI, Basel, Switzerland. This article is an open access article distributed under the terms and conditions of the Creative Commons Attribution (CC BY) license (https:/ / creativecommons.org/licenses/by/ $4.0 /)$.

\begin{abstract}
The aim of this work was to study effect of the type of silica nanoparticles on the properties of nanocomposites for application in the guided bone regeneration (GBR). Two types of nanometric silica particles with different size, morphology and specific surface area (SSA) i.e., high specific surface silica (hss-SiO 2 ) and low specific surface silica $\left(\mathrm{lss}-\mathrm{SiO}_{2}\right)$, were used as nano-fillers for a resorbable polymer matrix: poly(L-lactide-co-D,L-lactide), called PLDLA. It was shown that higher surface specific area and morphology (including pore size distribution) recorded for hss$\mathrm{SiO}_{2}$ influences chemical activity of the nanoparticle; in addition, hydroxyl groups appeared on the surface. The nanoparticle with 10 times lower specific surface area $\left(1 \mathrm{ss}-\mathrm{SiO}_{2}\right)$ characterized lower chemical action. In addition, a lack of hydroxyl groups on the surface obstructed apatite nucleation (reduced zeta potential in comparison to hss- $\mathrm{SiO}_{2}$ ), where an apatite layer appeared already after $48 \mathrm{~h}$ of incubation in the simulated body fluid (SBF), and no significant changes in crystallinity of PLDLA/lss- $\mathrm{SiO}_{2}$ nanocomposite material in comparison to neat PLDLA foil were observed. The presence and type of inorganic particles in the PLDLA matrix influenced various physicochemical properties such as the wettability, and the roughness parameter note for PLDLA/lss-SiO $\mathrm{increased}_{\text {. }}$ The results of biological investigation show that the bioactive nanocomposites with hss-SiO ${ }_{2}$ may stimulate osteoblast and fibroblast cells'proliferation and secretion of collagen type I. Additionally, both nanocomposites with the nanometric silica inducted differentiation of mesenchymal cells into osteoblasts at a proliferation stage in in vitro conditions. A higher concentration of alkaline phosphatase (ALP) was observed on the material modified with hss- $\mathrm{SiO}_{2}$ silica.
\end{abstract}

Keywords: nanoparticles; silica; nanocomposite; bioactivity; bone substitute; regenerative medicine

\section{Introduction}

Surgical procedures related to bone grafting are about 2 million orthopedic surgeries per year worldwide annually [1]. This demand for traditional solutions has led to a situation in which the Tissue Banks lack natural substitutes filling the defect and support rapid regeneration of bone tissue (the so-called gold standard). 
Numerous scientific studies indicate that synthetic bone substitutes (BGSs) should meet several features ensuring maximum structural and morphological fit to natural bone (structural and microstructural biomimetics) [2-4].

The ideal bone substitute should have the ability to allow space (scaffold) for the incoming cells and, at the same time, facilitate tissue reconstruction including neovascularization or bone canals [5]. Only the scaffold providing osteointegration into the tissue, i.e., providing conditions for cell adhesion and proliferation and giving a signal for cell differentiation, is currently the direction identified with the solution of many clinical problems [6-9]. Such problems include, for example, ceramic and synthetic bone substitutes based on hydroxyapatite (HAp), tricalcium phosphates (TCP), and bio glasses (BG) [10-12]. Completely resorbable porous ceramic materials mechanically based on TCP or BG provide osteoinductivity and osteoconductivity but do not meet the mechanical requirements $[13,14]$. Low mechanical strength (less than the cortical bone), brittleness, and low handiness (difficulty to cut under operating conditions) are a problem in clinical conditions. However, modifications in the chemical structure of apatite ( $\mathrm{Si}, \mathrm{Sr}, \mathrm{Fe}$, and $\mathrm{Mg}$ ion substitution) and bioglass (addition of $\mathrm{MgO}, \mathrm{SrO}$, or $\mathrm{ZnO}$ oxides) allow to achieve better structural mimetics of the substitute, but do not significantly improve its mechanical properties while maintaining high bioactivity [15-19].

The second material approach is the use of composites and nanocomposites based on resorbable polymers inducing the right cellular response. Polylactides are commonly praised for their excellent mechanical properties (e.g., high modulus and yield strength) and possibility to control durability of an implant in in vitro conditions (e.g.,; by different isomeric L to DL ratio). PLDLA has a structure that combines the best characteristics of poly (L-lactic acid) and poly (D-lactic acid), i.e., the mechanical properties of the first and the shorter degradation time of the second [1,4]. Among bioresorbable polymer materials, polyL/DL-lactide (PLDLA) has FDA approval, which guarantees its application as an implant in orthopedic medicine. Our study confirms that the presence of inorganic nanoparticles (i.e.,; $\mathrm{SiO}_{2}$ ) stimulating bone cells growth on resorbable implant based on PLDLA is an effective method for initiating the regeneration process.

Polymer-ceramic nanocomposites may contribute to the production of biocompatible implant materials with adequate strength and are capable of stimulating the reaction of repair cells and proliferation of bone cells [20-23]. This task may be accomplished by altering a surface energy and/or surface topography of the nanocomposite by the addition of a specific amount of bioactive nanoparticles such as silica [24-26]. Nanocomposites filled with bioactive ceramic nanoparticles such as nanometric tricalcium phosphate (TCP) or hydroxyapatite (HAp) are examples of such biomimetic materials. The main task of a bioactive nanofiller is to induce a specific biological reaction leading to a formation of a bond between natural bone and an implant material [21,23,27]. Because of their high specific surface area, which is inversely proportional to the particles size, the nanoparticles may have a strong impact on the surrounding material. Nanoparticles, as it is known from the literature, are characterized by a different ratio between mass and area than conventional particles of micrometric size.

Silicon dioxide $\left(\mathrm{SiO}_{2}\right)$ or silica is a ceramic additive, which was successfully applied in implant materials for bone surgery. Up to now, it has mainly been deposited as layers or applied in the form of particles modifying the implant's surface [28-30]. Silica plays the crucial role in the bio-mineralisation process by enhancing bioactivity of a material due to the presence of silanol groups ( $\mathrm{SiOH}-$ ) at its surface, which favours the formation of hydroxyapatite in in vivo conditions [31-33]. Bioactivity of micrometric silica particles depends on its surface charge, composition, structure, and morphology. During their immersion in the simulated body fluid (SBF), a significant amount of silanol groups appeared, which then led to the formation of silica gel and consequently to apatite layer. The phenomenon of apatite formation on silica was explained by numerous studies $[34,35]$. According to them, adsorption of calcium ions, which was stronger than adsorption of 
phosphate ions, is the initial step of apatite nucleation. This phenomenon strongly depends on the $\mathrm{pH}$ of the solution as well as on zeta potential of the silica particles [35-37].

Nanometric silica having a high specific surface and thus a high amount of exposed silanol groups seems to be an interesting osteoconductive filler in nanocomposites destined for bone implants [27,34]. The incorporation of silica nanoparticles into the polymer matrix stimulated osteoblast-like cells interaction with natural tissue after contact with the material's surface i.e.,; cells viability increased since $\mathrm{Si}$ (at critical concentrations) is able to stimulate proliferation of MG-63 cells [24,38]. Si also can be involved in bone formation and mineralization [39], whereas orthosilicate acid $\left(\mathrm{Si}(\mathrm{OH})_{4}\right)$ at a physiological concentration of $10 \mu \mathrm{mol}$ was shown to stimulate the formation of collagen type I in human osteoblast cells (HOC) and osteoblastic differentiation [40].

The experimental approach in the topic of bone tissue regeneration with bone substitutes consists in the preparation of a polymer substrate on which the patient's own cells are applied. In some cases, they have been used as bioactive carriers providing local osteoinductive genes-starting the bone regeneration process. For this purpose, mesenchymal stem cells, which are multi-potential cells capable of effective use of osteogenic potential, are widely used. In our work, we show that a necessary condition to stimulate the regeneration process with the use of nanocomposite materials based on PLDLA by mesenchymal stem cells is the presence of an appropriate active nanoparticle. The comparison of silica nanoparticles shows that not all of them have the same chemical potential that can have a real impact on the processes related to the metabolic activation of cells i.e.,; proliferation or secretion. The proposed research methodology used for the nanoparticles allows to select the nanoparticle with the highest bioactive potential. It could be used instead of performing a series of tedious studies on the preparation of a homogeneous nanocomposite that could have bioactive properties.

\section{Materials and Methods}

Poly(L-lactide-co-D,L-lactide) polymer (Boehringer Ingelheim, Ingelheim am Rhein, Germany) was used as a matrix material. Molecular weight of the polymer was $200 \mathrm{kDa}$, and L-lactide to D,L-lactide ratio was 80:20. The polymer matrix was modified using nanometric powders of both low specific surface area silica-lss- $\mathrm{SiO}_{2}$ (Arco S.A., Poznan, Poland), and high specific surface area silica-hss-SiO 2 (Sigma Aldrich Com, Munich, Germany).

Polymer-ceramic nanocomposite membrane preparation: polymer-ceramic nanocomposite materials in the form of thin foils were produced using a casting method. The polymer was dissolved in dichloromethane $\left(\mathrm{CH}_{2} \mathrm{Cl}_{2}\right.$, POCh S.A.) (1:10 wt. ratio) and then $0.5 \mathrm{wt} . \%$ of a given silica powder dispersed in $\mathrm{CH}_{2} \mathrm{Cl}_{2}$ was introduced and ultrasonicated for $5 \mathrm{~min}$. After mechanical stirring of the polymer solution and the silica dispersion, the polymer mixture was cast on a Petri dish and then the solvent was evaporated at room temperature $(6 \mathrm{~h})$ using a dryer $\left(80^{\circ} \mathrm{C} / 24 \mathrm{~h}\right)$.

The silica powders were analysed in terms of particle size distribution (DLS method, Zetasizer Nano-ZS, Malvern Ins., Worcestershire, United Kingdom), particle morphology (TEM, JEOL_JEM1011, Freising, Germany), specific surface area (BET), and porosity (nitrogen adsorption at 77K, BJH method; Nova 1200e, Quantachrome Inc., Boynton Beach, FL, USA). The presence of surface groups was investigated using FT-IR (Bio-Rad Excalibur spectrometer, Bio-Rad Polska Sp. z.o.o., Warszawa, Polska). For the infrared analysis, powder samples were prepared in the form of potassium bromide (KBr) pellets (transmission mode). For better analysis of the nanoparticles surface, the Diffuse Reflection mode (DRIFTs) was used. The silica powders were diluted in a nonabsorbent matrix (KBr). Additionally, zeta potential changes of the silica powders immersed in SBF with time were determined by Laser-Doppler Velocimetry Electrophoresis method (Zetasizer Nano-ZS, Malvern Ins., Worcestershire, UK).

In order to verify if the produced materials have nanocomposite character, they were subjected to thermal analysis using differential scanning calorimetry in an inert gas 
atmosphere (helium) at temperatures from $50{ }^{\circ} \mathrm{C}$ to $300{ }^{\circ} \mathrm{C}$, with a heating rate of $10^{\circ} \mathrm{C} / \mathrm{min}$ (DSC 2010, TA Instruments).

The effect of $\mathrm{SiO}_{2}$ nanoparticles on material topography was determined using an atomic force microscope (AFM, Bruker MultiMode V microscope, Digital Inst., Burlington, MA, USA). The contact mode was used, which determined the most important topography parameters i.e., Ra (mean surface roughness) and RMS (effective roughness) over a $100 \times 100 \mu \mathrm{m}$ test area. The sensitivity of the measurement system was less than $100 \AA$. Wettability of the surface with polar and non-polar liquid was measured using a goniometer (DSA 25, Kruss, Hamburg, Germany) by the direct measurement method. The tests were carried out at atmospheric conditions using high purity water (UHQ, PURE Lab, Vivendi water, Poznan, Poland) as the liquid for wettability determination and diiodomethane as the non-polar liquid. The surface free energy was determined using the Owens-Wendt method.

A bioactivity test was performed by incubation of all materials in simulated body fluid (SBF), and the biological response was assessed based on the interaction with fibroblasts (HS-5, ATCC) and osteoblasts of rats (I Local Ethics Committee in Krakow, Poland No. $25 / 2007)$. SBF is an artificial body fluid with $\mathrm{pH}$ and ion concentration similar to human body fluid, but free from proteins and cells, and its chemical composition is presented in Table 1 . The incubation enabled to create in vitro conditions, facilitating the formation of an apatite layer on the material's surface. The samples were incubated at $37^{\circ} \mathrm{C}$ for 3 days. The microstructure of the samples after 3 days of SBF incubation was examined using scanning electron microscope (JMS-5400, JEOL, Osaka, Japan).

Table 1. Chemical composition of simulated body fluid (SBF) and body plasma $(\mathrm{pH}=7.4)[25,40]$.

\begin{tabular}{ccccccccc}
\hline \multirow{2}{*}{ Fluid } & \multicolumn{7}{c}{ Concentration of Ion (mM) } \\
\cline { 2 - 8 } & $\mathbf{C l}^{-}$ & $\mathbf{H C O}_{3}{ }^{-}$ & $\mathbf{H P O}_{4}{ }^{2-}$ & $\mathbf{S O}_{4}{ }^{2-}$ & $\mathbf{N a}^{+}$ & $\mathbf{K}^{+}$ & $\mathbf{M g}^{2+}$ & $\mathbf{C a}^{2+}$ \\
\hline Body Plasma & 103.0 & 27.0 & 1.0 & 0.5 & 142.0 & 5.0 & 1.5 & 2.5 \\
\hline $\begin{array}{c}\text { Simulated Body } \\
\text { Fluid, SBF }\end{array}$ & 148.8 & 4.2 & 1.0 & 0.5 & 142.0 & 5.0 & 1.5 & 2.5 \\
\hline
\end{tabular}

Fibroblasts (HS-5, ATCC CRL-11882) and osteoblasts (MG-63, ATCC CRL-11372) of $2 \times 10^{-4}$ concentration were cultured on the investigated materials inside $12 \mathrm{~h}$ 'ole culture plates. For fibroblast cells, RPMI culture medium (Sigma Aldrich Com, Munich, Germany) was applied enriched in $15 \%$ of fetal calf serum (FCS). Temperature of the culture was $37^{\circ} \mathrm{C}$. In the case of osteoblast-like cells, a 1:1 mixture of F12 HAM nutrient medium and Dulbecco modification of Eagle medium (DME F12, Sigma Aldrich Com, Munich, Germany) was applied without phenol red with the addition of $10 \%$ of fetal calf serum. The culture temperature was $34^{\circ} \mathrm{C}$. Viability of cells was determined using CellTiter 96 AQueous One Solution Cell Proliferation Assay (MTS, Promega, Madison, WI, USA). Collagen type-I concentration was determined using Collagen Type I ELISA test using Bioproducs (Lussane, Switzerland) antibodies and standards. The statistical analysis was based on Fisher's exact test and Student's $t$-test.

Trabecular bone fragments were obtained from the bone of rats (I Local Ethics Committee in Krakow, Poland No. 25/2007). Cell isolation preparation was based on the protocol first described by Robey and Termine [41,42]. A fragment of rat spongy bone was collected and minced [ethics committee approval]. Tissue homogenization was carried out by shredding with surgical scissors in DMEM/F-12K (Sigma Aldrich Com, Munich, Germany) enriched with antibiotics (50 IU penicillin $/ \mathrm{mL}, 50 \mathrm{mg}$ streptomycin/mL, Sigma Aldrich Com, Munich, Germany). In the next step, the biological material was incubated in immersion medium under conditions simulating a living organism: $37^{\circ} \mathrm{C} / 3-4 \mathrm{~h}$ in an air atmosphere with $5 \% \mathrm{CO}_{2}$ until the cellular material on the bone surface disappeared. The immersion medium consisted of DMEM/F-12K, $2 \mathrm{mM} \mathrm{L-glutamine,} 50 \mathrm{lg} / \mathrm{mL}$ ascorbate, $256 \mathrm{U} / \mathrm{mL}$ collagenase type $\mathrm{XI}$, and antibiotics. The minced bone fragments were then rinsed with $0.9 \%$ sodium chloride (Baxter). The cultures were prepared by incubating 
the biological material in medium containing calcium-free DMEM/F12-K supplemented with $10 \%$ fetal bovine serum (FBS), $2 \mathrm{mM}$ L-glutamine, $50 \mathrm{lg} / \mathrm{mL}$ ascorbate, and antibiotics. The cultures were kept at $37^{\circ} \mathrm{C} / 3-4$ days in an air atmosphere with $5 \% \mathrm{CO}_{2}$. The confluent cell layer was trypsinized (0.25\% trypsin containing $1 \mathrm{mM}$ EDTA, Sigma Aldrich Com, Munich, Germany) and counted in a hemocytometer.

The cell viability on the surface of the pure polymer and nanocomposite materials was performed using prime culture of mesenchymal cells (MSCs). Viability of cells was determined using CellTiter 96 AQueous One Solution Cell Proliferation Assay (MTS, Promega $\mathrm{GmbH}, \mathrm{GmbH}$, Madison, WI, USA). The ALP activity test was performed using a commercial ELISA substrate kit (Life Technologies Polska Sp. z. o. o., Warsaw, Poland). ALP activity was tested at three time intervals: 7, 14, and 21 days of the cell culture. After adequate cell culture time, the nanocomposite films were washed with PBS and then $400 \mu \mathrm{L}$ of p-nitrophenyl phosphate was added to each well; after 30 min of incubation, $200 \mu \mathrm{L}$ of $2 \mathrm{M} \mathrm{NaOH}$ was added to inhibit the reaction (hydrolysis of p-nitrophenyl phosphate to p-nitrophenol and phosphate, causes color change). The absorbances of the obtained solution at $405 \mathrm{~nm}$ were read using a microplate reader (GloMax ${ }^{\circledR}$ Discover Microplate reader, Promega GmbH, Madison, WI, USA).

\section{Results}

One of the most important factors effecting properties of nanocomposite materials is the characteristics of applied additives (fillers). Since in both nanocomposite materials the amount of silica was the same $(0.5 \% \mathrm{w} / \mathrm{w})$ and they were prepared in the same manner, the only reason for changes in their behavior could be differences in the filler characteristics.

Nanoparticles characteristics: Particle size distribution in the case of hss- $\mathrm{SiO}_{2}$ powder was broad with a modal value of $220 \mathrm{~nm}$ and narrower in the case of $1 \mathrm{ss}-\mathrm{SiO}_{2}$ with a modal value around $140 \mathrm{~nm}$ (Table 2). Particle size distributions were determined by DLS method in diluted, well dispersed $(\mathrm{pH}=2)$ water suspensions, and the results may be treated as the limit distribution, which can be achieved in conditions of very effective dispersion of the powders (Figure 1).

Table 2. Characteristics of the silica nanoparticles used in experiments.

\begin{tabular}{ccc}
\hline Nanoparticles Characteristics & hss-SiO & lss-SiO $_{\mathbf{2}}$ \\
\hline Modal particle diameter, DLS $(\mathrm{nm})$ & 220 & 142 \\
\hline Mean particle size, TEM $(\mathrm{nm})$ & 60 & 50 \\
\hline Specific surface area, BET $\left(\mathrm{m}^{2} / \mathrm{g}\right)$ & 582.8 & 65.8 \\
\hline
\end{tabular}

Probably in the case of actual silica dispersions used for the composites' production, the agglomerate size was larger. Mean size of the primary particles estimated on the basis of TEM microphotographs (Figure 1) was c.a. 50 and $60 \mathrm{~nm}$ in the case of $1 \mathrm{ss}^{-\mathrm{SiO}_{2}}$ and hss- $\mathrm{SiO}_{2}$, respectively. The comparison between the primary particles size (TEM) and agglomerates size (DLS) suggested that the applied dispersion method did not sufficiently break the agglomerates, because there was no evidence of the primary particles in the suspension. TEM microphotographs suggested that wide contacts between the primary particles were formed, which means that breaking them with the use of sole ultrasounds might be very difficult or even impossible. 

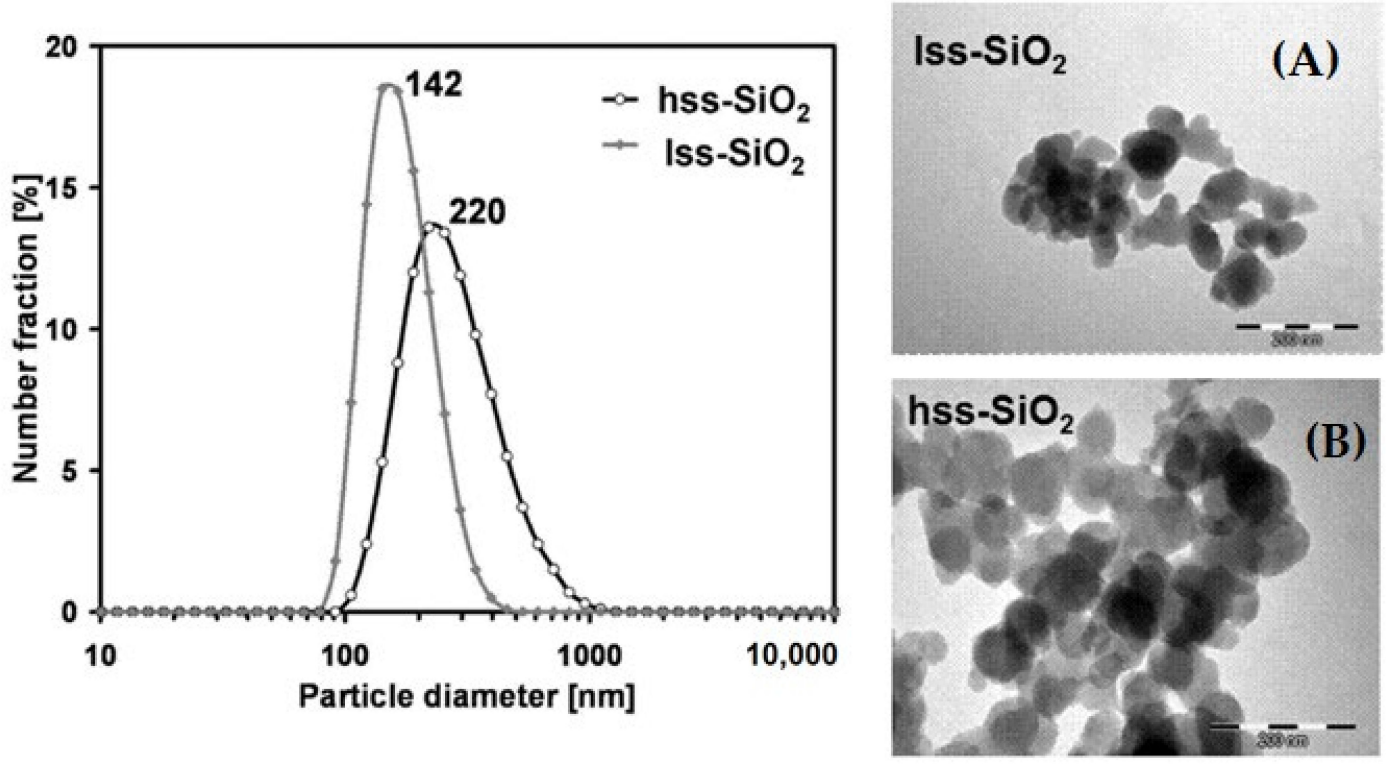

Figure 1. Particle size distribution of silica powders determined by DLS method (water, $\mathrm{pH}=2$ ) and TEM morphology of: lss- $\mathrm{SiO}_{2}(\mathbf{A})$ and hss-SiO 2 (B) powders.

Despite a rather similar particle size, both powders revealed quite different specific surface areas (Table 2), which were $582.8 \mathrm{~m}^{2} / \mathrm{g}$ and $65.8 \mathrm{~m}^{2} / \mathrm{g}$ for hss- $\mathrm{SiO}_{2}$ and $1 \mathrm{ss}-\mathrm{SiO}_{2}$, respectively. The high specific surface area of hss- $\mathrm{SiO}_{2}$ was related to the presence of a relatively high amount of micropores i.e., pores of sizes smaller than $2 \mathrm{~nm}$ (according to IUPAC definition) (Figure 2). Due to technical limitations of the apparatus used, it was impossible to determine pores smaller than $2 \mathrm{~nm}$, but the pore size distribution curves may suggest that such pores existed in both silica powders. In the case of $1 \mathrm{ss}-\mathrm{SiO}_{2}$, the number of such pores was smaller, and the porosity mainly consisted of mesopores i.e., pores of diameter between 2 and $100 \mathrm{~nm}$. Such pores existed in both powders and most probably were related to intra-agglomerate porosity.

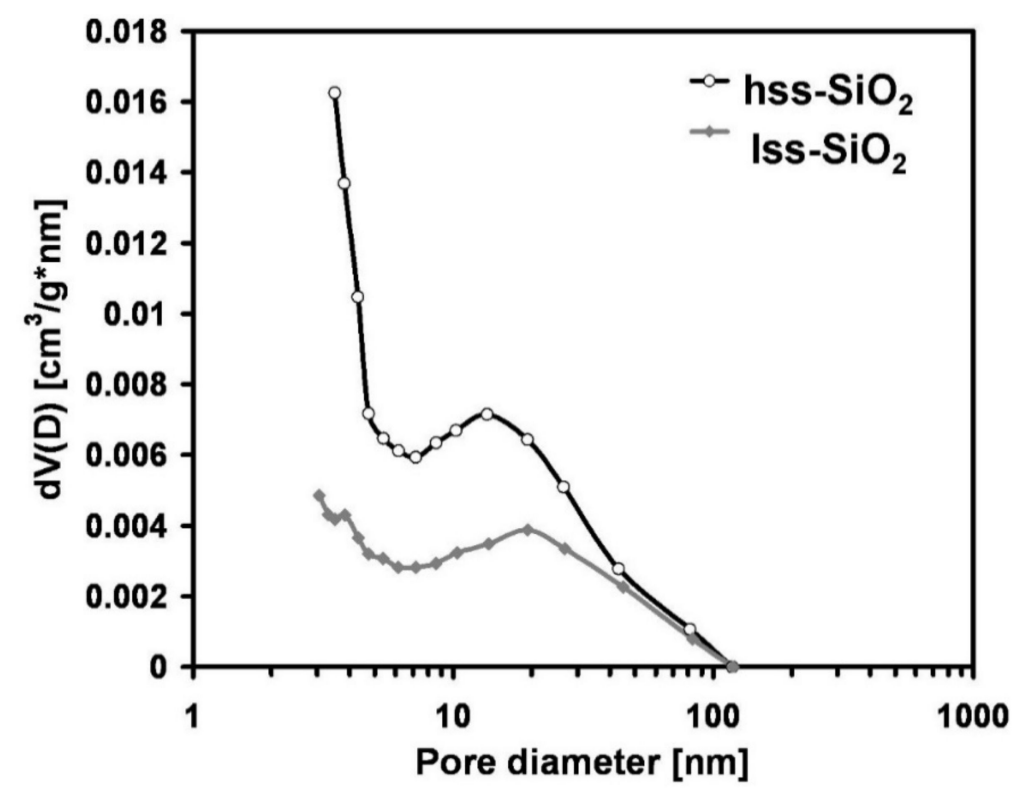

Figure 2. Pore size distribution of the silica powders determined from the desorption branch of nitrogen adsorption/desorption isotherms using BJH method (temperature $77 \mathrm{~K}$ ). 
FTIR spectra of the silica nanoparticles showed subtle differences between the powders. Conventional transmission mode indicated typical bands belonging to Si-O-Si bending vibrations at $470 \mathrm{~cm}^{-1}$ and $810 \mathrm{~cm}^{-1}$ and Si-O groups in the range of $1100 \mathrm{~cm}^{-1}$ belonging to stretching vibrations. Bands at $960 \mathrm{~cm}^{-1}$ are characteristic for $\mathrm{Si}-\mathrm{OH}$ stretching vibration $[43,44]$. The bands in the region 3650 to $3750 \mathrm{~cm}^{-1}$ belonged to hydrogen bonding (Figure $3 \mathrm{~A}$, curves: $\mathrm{a}, \mathrm{b}$ ). These results were confirmed using DRIFTs technique (Figure 3A, curves c,d). Stronger bands in $1680 \mathrm{~cm}^{-1}$ confirmed hydrogen-bonded water present on the silica surface. The precise analysis of the FTIR spectra range characteristic for hydrogen bonding is shown in Figure 3B. Adsorption bands at $3680-3750 \mathrm{~cm}^{-1}$ were attributed to surface hydroxyl groups (Figure 3B, curves: c,d).
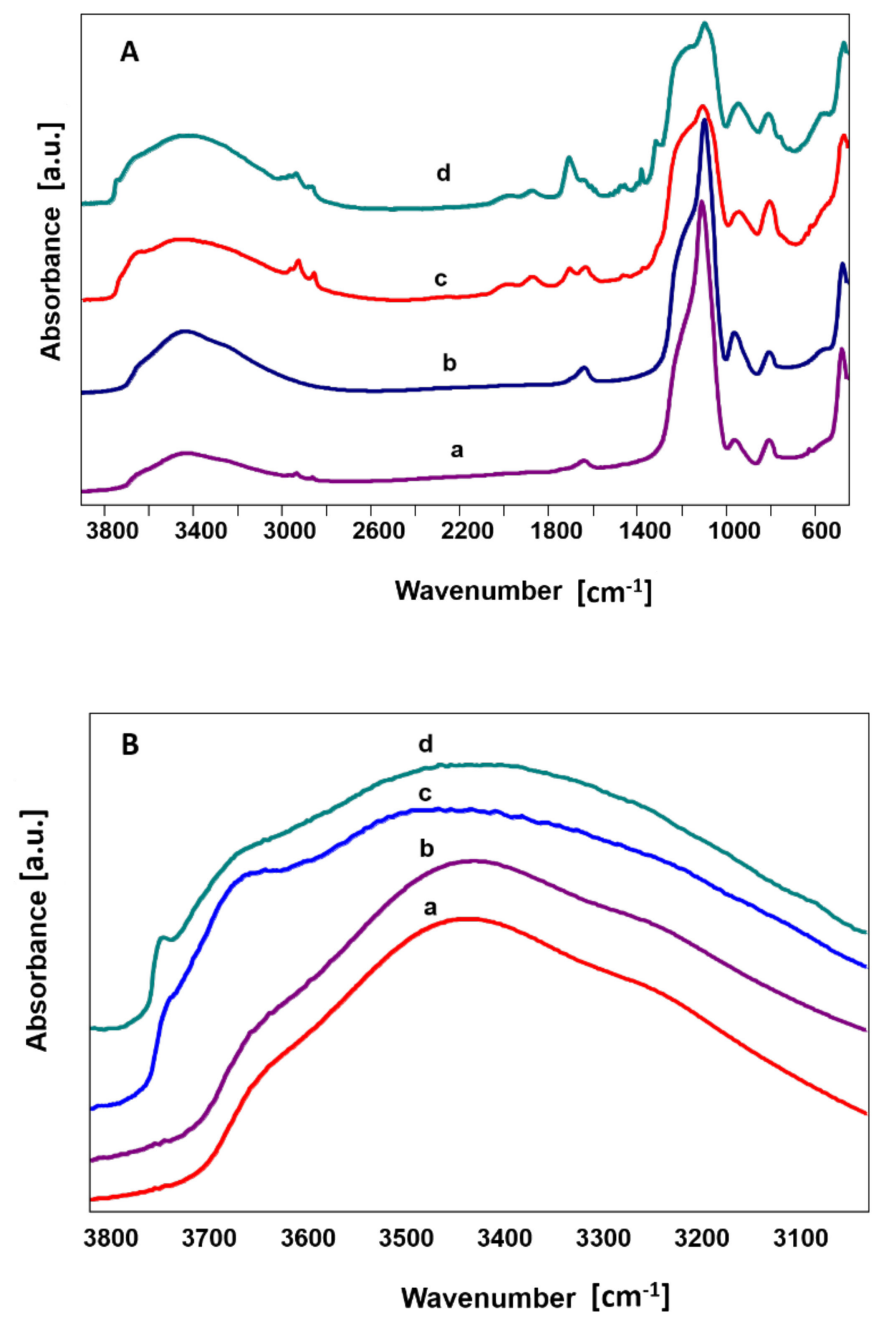

Figure 3. FTIR spectra of silica nanoparticles: lss- $\mathrm{SiO}_{2}(\mathrm{a}, \mathrm{c})$ and hss-SiO $2(\mathrm{~b}, \mathrm{~d})$ in all spectrum 580-3800 $\mathrm{cm}^{-1}$ (A). FTIR spectra in transmission mode $(\mathrm{a}, \mathrm{b})$ and in DRIFTs mode $(\mathrm{c}, \mathrm{d})$ in the range 3000-3800 $\mathrm{cm}^{-1}$ (B).

Nanocomposite materials characterisation: Thermal analysis (TG/DSC) of the fabricated nanocomposite materials revealed that glass transition temperature $\left(\mathrm{T}_{\mathrm{g}}\right)$ and malting temperature $\left(\mathrm{T}_{\mathrm{m}}\right)$ at DSC curves and thermal degradation temperature $\left(\mathrm{T}_{\mathrm{deg}}\right)$ in thermogravimeter analyses (TG) shifted towards higher values of $\mathrm{PLDLA} / \mathrm{hss}-\mathrm{SiO}_{2}$ in relation to the pure polymer.

In the results shown in Table 3, glass transition temperature Tg occurred around $50-60{ }^{\circ} \mathrm{C}$ for all samples. Melting occurred with endothermic peaks at the temperature $\mathrm{Tm}$ around $160-170{ }^{\circ} \mathrm{C}$ for the nanocomposite materials samples. The degradation temperature of the PLDLA was $356.7^{\circ} \mathrm{C}$ and it shifted to $350.3{ }^{\circ} \mathrm{C}$ and $348.2{ }^{\circ} \mathrm{C}$ for the composite 
containing hss- $\mathrm{SiO}_{2}$ and lss- $\mathrm{SiO}_{2}$, respectively. These results show that the crystallinity of the material was higher when the nano-filler was hss- $\mathrm{SiO}_{2}$. The probable cause of this phenomenon is the higher specific surface area (SSA) (BET, shown in Table 2 in the manuscript) of the hss- $\mathrm{SiO}_{2}$ nanoparticles (almost $10 \times$ higher than SSA of the lss$\mathrm{SiO}_{2}$ ) and the stronger interaction between the polymer chain and particle, resulting in increased crystallinity. The difference between the thermal degradation temperature of both nanocomposite materials was not significant, which was probably caused by the similar particle size and interaction level of both silica powders. Nevertheless, it was a proof of interaction between silica particles and the polymer chains [33].

Table 3. Thermal properties of the nanocomposite foils and the pure polymer.

\begin{tabular}{ccccc}
\hline Material & $\mathbf{T}_{\mathbf{g}},{ }^{\circ} \mathbf{C}$ & $\mathbf{T}_{\mathbf{m}},{ }^{\circ} \mathbf{C}$ & $\mathbf{T}_{\mathbf{d e g}},{ }^{\circ} \mathbf{C}$ & $\lambda, \boldsymbol{\%}$ \\
\hline PL/DLA & 57.3 & 162.5 & 356.7 & 36.5 \\
\hline PL/DLA hss-SiO 2 & 59.8 & 168.2 & 350.3 & 40.2 \\
\hline PL/DLA lss-SiO 2 & 57.2 & 161.8 & 348.2 & 37.6 \\
\hline
\end{tabular}

In the case of composites, such properties can be altered by the addition of a proper type and amount of a filler. The presence of $0.5 \mathrm{w} \%$ of the nano-fillers in the polymer matrix influenced the roughness of the composites surface as well as it changed its physicochemical parameters. The highest mean roughness profile (RMS) was observed in the case of the composite containing lss-SiO ${ }_{2}$; it was $29.6 \mathrm{~nm}$, compared to $22.6 \mathrm{~nm}$ for the composite containing hss-SiO${ }_{2}$ and $19.1 \mathrm{~nm}$ for the pure polymer. The roughness increase was caused by the presence of surface pores that were revealed by AFM observations (Figure 4). Such surface pores did not exist in the case of the pure polymer and composite containing hss$\mathrm{SiO}_{2}$. This was probably an effect of $1 \mathrm{ss}-\mathrm{SiO}_{2}$ particles agglomeration. The solvent wetted the nanoparticles and evaporated faster from their surface than from bulk polymer, which caused the creation of pin holes on the nanocomposite surface. The results of roughness and thermal analysis of the material based on $1 \mathrm{ss}-\mathrm{SiO}_{2}$ proved inhomogeneous dispersion of the nanofiller in the polymer matrix.

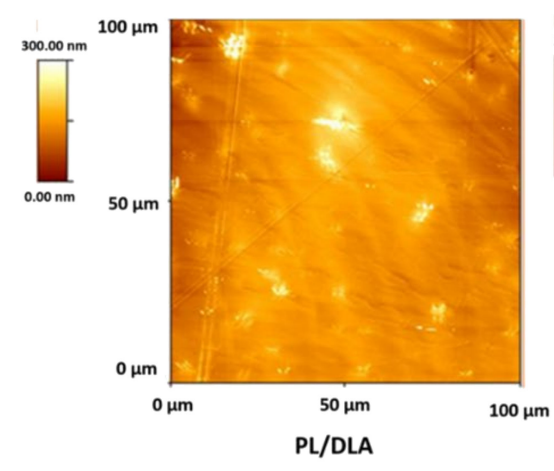

$R_{\mathrm{a}}=13.2 \mathrm{~nm}$ $R_{\mathrm{MS}}=19.1 \mathrm{~nm}$

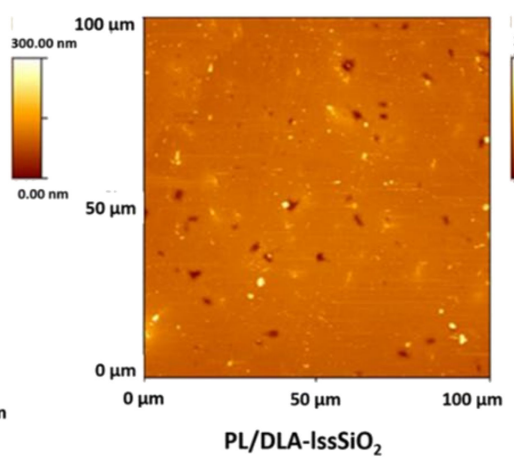

$R_{\mathrm{a}}=16.9 \mathrm{~nm}$

$R_{\mathrm{MS}}=29.6 \mathrm{~nm}$

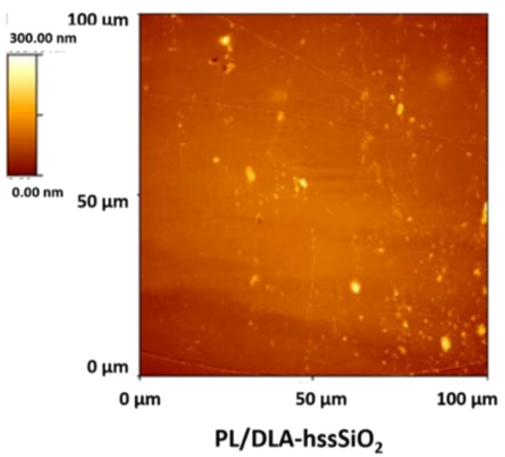

$R_{\mathrm{a}}=17.8 \mathrm{~nm}$

$\mathbf{R}_{\mathrm{MS}}=\mathbf{2 2 . 6 \mathrm { nm }}$

Figure 4. Topography of the nanocomposite materials and the polymer foil (reference sample) with characteristic parameters $\mathrm{R}_{\mathrm{a}}$ and RMS.

While the addition of the silica nanopowders to the polymer matrix causes a slight change in the wettability of the nanocomposite film (Figure 5A), the value of the surface free energy is changed (Figure 5B). The addition of $1 \mathrm{ss}^{-\mathrm{SiO}_{2}}$ causes a decrease in the total surface free energy (about $40 \mathrm{~mJ} / \mathrm{m}^{2}$ ), while the introduction of hss- $\mathrm{SiO}_{2}$ into the polymer matrix causes an increase in the total surface free energy $\left(46 \mathrm{~mJ} / \mathrm{m}^{2}\right)$. The decrease in wettability for PLDLA/hss-SiO ${ }_{2}$ and the increase in surface energy may be a synergistic 
effect related to the surface topography of the nanocomposite [45]. The obtained results may implicate the cellular response to the material in the in vitro tests with cells.

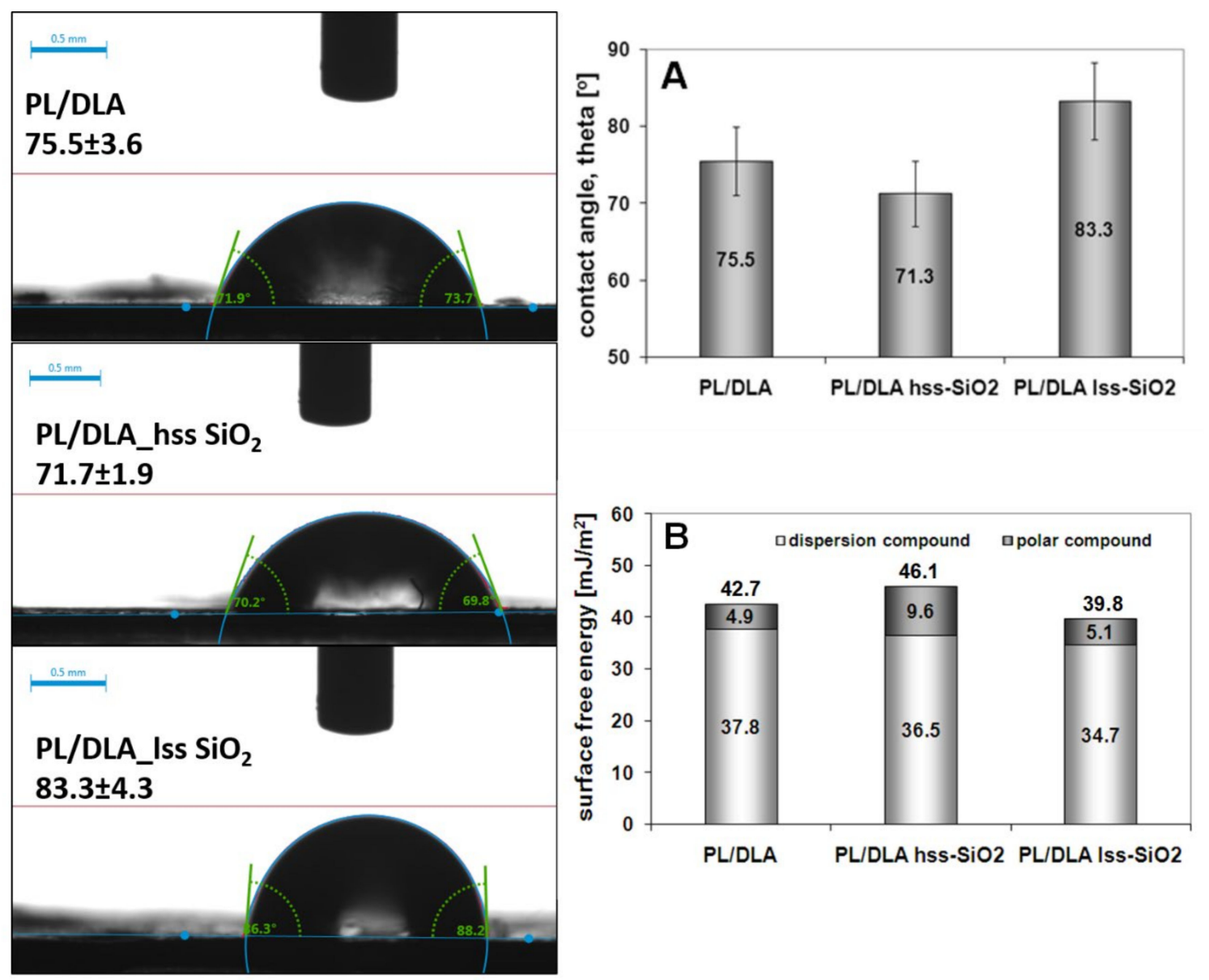

Figure 5. Results of contact wetting angle of the pure polymer and the nanocomposites materials (A) and contact angle images of the samples. Surface energy of the pure polymer and the composites (B).

Silica particles are known for their biological activity. After the incubation test $\left(\mathrm{SBF} / 3\right.$ days $\left./ 37^{\circ} \mathrm{C}\right)$, the surface of PL/DLA hss-SiO ${ }_{2}$ composite was covered with characteristic apatite structures (Figure 6A), and EDS microanalysis of those structures indicated the presence of $\mathrm{Ca}$ and $\mathrm{P}$ ions characteristic for apatite. Such structures were not observed in the case of material containing $1 \mathrm{ss}-\mathrm{SiO}_{2}$ (Figure 6B).

Both silica powders had similar zeta potential at the beginning of the incubation in simulated body fluid (SBF). During the incubation time, zeta potential of $1 \mathrm{ss}^{-\mathrm{SiO}_{2}}$ was increasing until $96 \mathrm{~h}$ and then decreased (Figure 7). Changes of zeta potential of hss-SiO during the incubation had different characteristics; until $48 \mathrm{~h}$, the potential increased to $0 \mathrm{mV}$ and remained almost constant. The most important was zeta potential value after $72 \mathrm{~h}$ ( 3 days) of incubation because SEM microphotographs of the materials surface after this time revealed, in the case of the nanocomposite containing hss-SiO ${ }_{2}$, characteristic apatite structures. This experiment showed that nanosilica is bioactive when the potential zeta value is close to $0 \mathrm{mV}$ [37]. High surface area did not influence the bioactivity of the nanosilica, but the most important feature was electric charge present on the silica nanoparticles surface. 

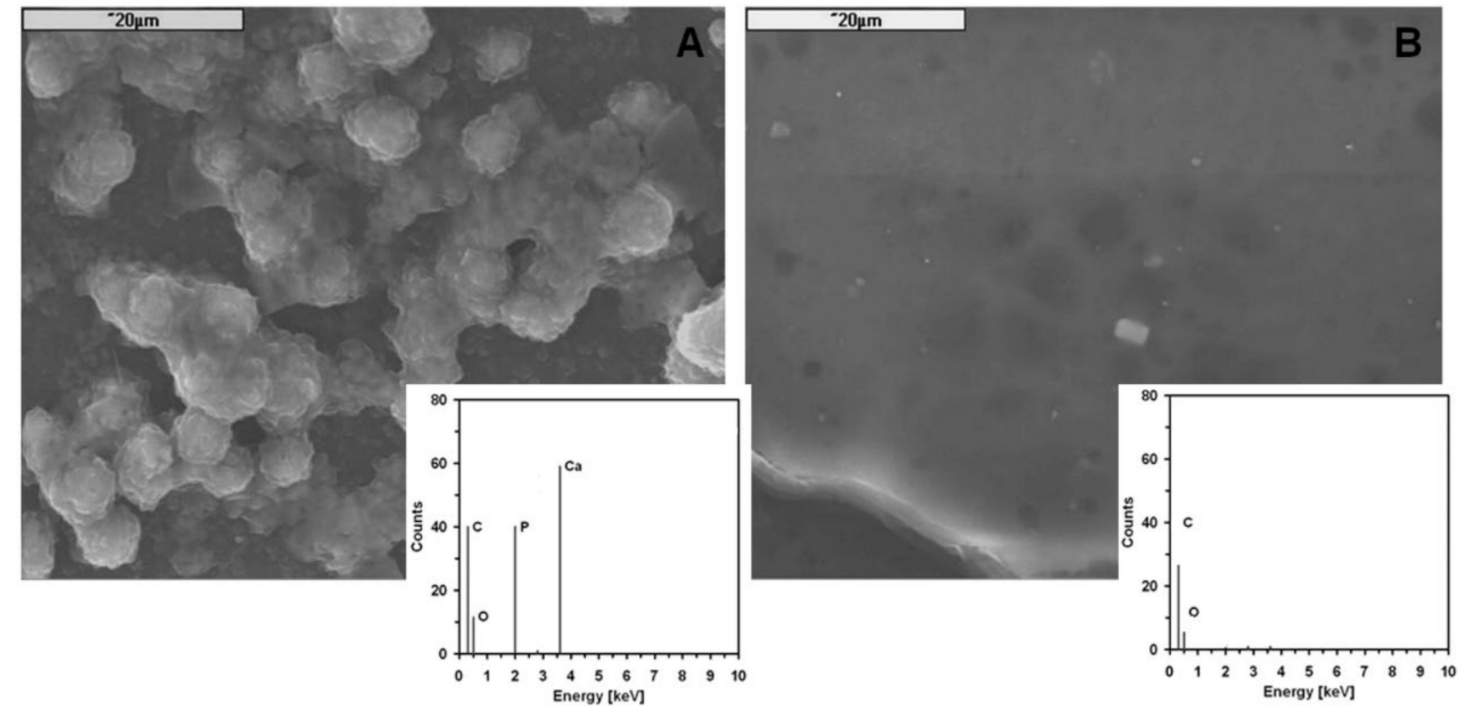

Figure 6. SEM microphotographs of the surface of composites containing 0.5 wt.\% of: hss $-\mathrm{SiO}_{2}(\mathbf{A})$ and lss- $\mathrm{SiO} \mathrm{O}_{2}(\mathbf{B})$ and EDS analysis of the surface of the composite after $\mathrm{SBF} / 3$ days $/ 37^{\circ} \mathrm{C}$.

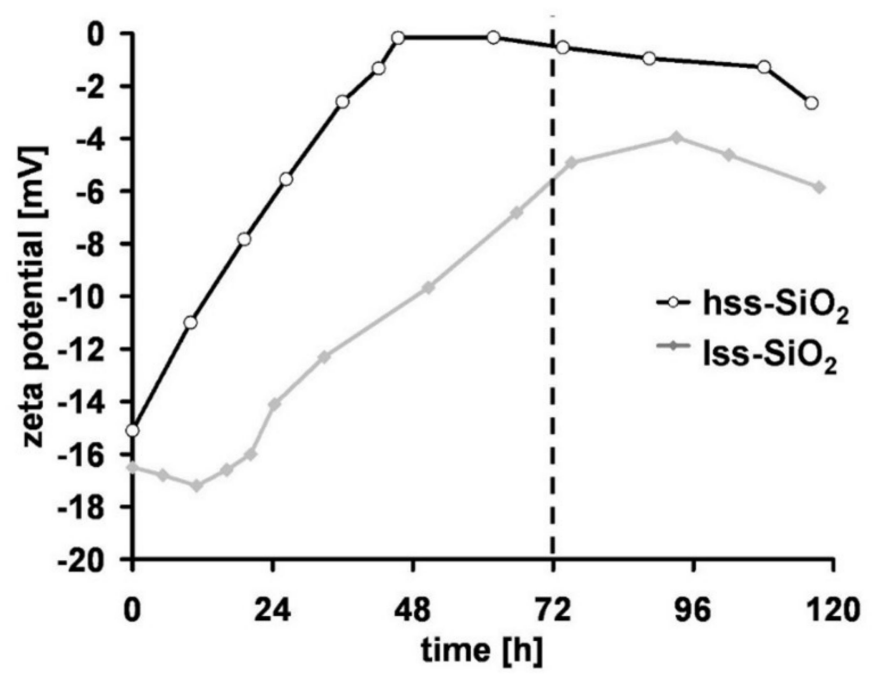

Figure 7. Changes of zeta potential of the silica powders vs. time $\left(\mathrm{SBF}, 37^{\circ} \mathrm{C}\right)$.

Biological studies of nanocomposite materials: Standard test of cells viability (MTS) showed high activity of mitochondrial enzyme, which certifies biocompatibility of the material (Figure 8). Results of the viability of mesenchymal stem cells that contacted with the active surface of the nanocomposite PL/DLA showed that the material modified with hss- $\mathrm{SiO}_{2}$ was a better support for the bone cells, which could proliferate. This nanocomposite was also characterized by bioactivity futures, which can be an important parameter in the differentiation of osteoblast cells [46]. The MSCs were grown on PLDLA/hss-SiO 2 nanocomposites and showed significantly higher $(p<0.05)$ proliferation levels, compared to those grown on PLDLA foil and PLDLA/lss-SiO 2 nanocomposite, due to the presence of a domain on the surface, which decreased the hydrophobicity of the nanocomposite for adhesion of cells (Figure 8A). It is known that alkaline phosphatase (ALP) is a primary phenotypic indicator secreted by osteoblasts. The intensity of ALP secretion indicates the early osteogenesis stage. Level assessment of ALP in the fabricated PLDLA, PLDLA/lss-SiO 2 and PLDLA/hss-SiO 2 foils will help to validate differentiation of MSCs towards anosteogenic lineage. As observed in Figure 8B, PLDLA/hss-SiO 2 nanocomposite foil shows a 
significantly increased $(p<0.05)$ level of ALP expression when compared to PLDLA and PLDLA/lss-SiO 2 after 14 and 21 days.
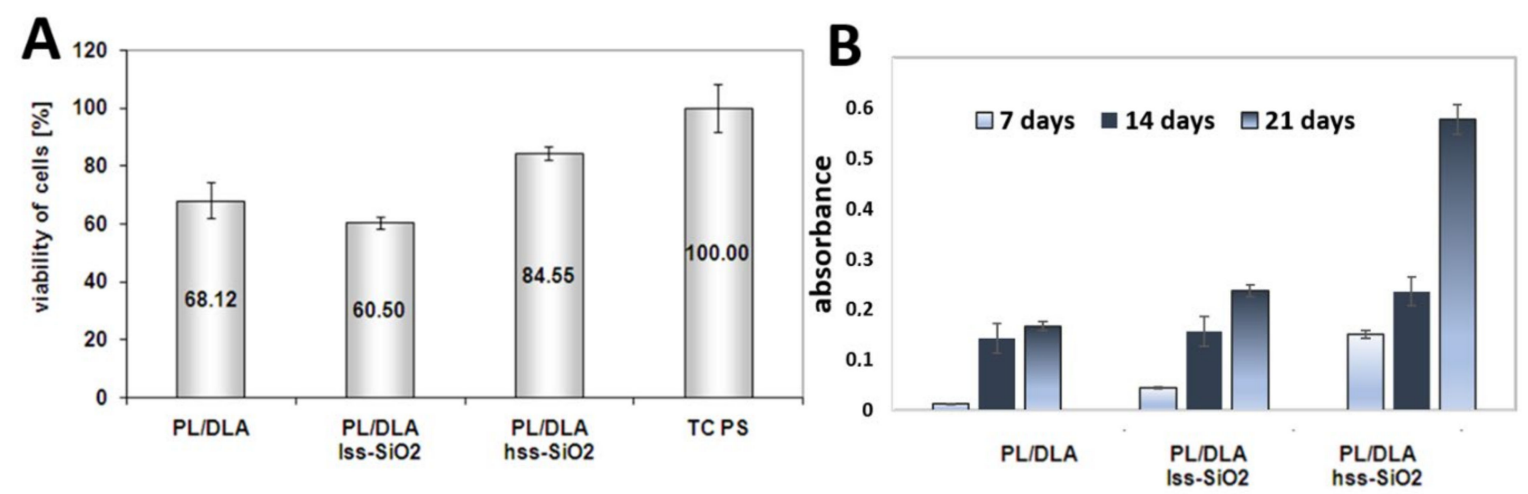

Figure 8. Viability of mesenchymal stem cells contacted with the nanocomposite membrane and the pure polymer membrane (A). TC PS was used as the reference sample. Alkaline phosphatase activity on PLDLA, PLDLA $/ 1 \mathrm{ss}-\mathrm{SiO} 2$ and PLDLA/hss-SiO 2 using MSCs on day 7, 14, and 21 (B).

Comparing two kinds of nanocomposites, the more promising material is polylactide modified with hss- $\mathrm{SiO}_{2}$ nanoparticles. For this reason, a next biological experiment was conducted. Nanocomposite PL/DLA foil containing hss-SiO 2 particles were contacted with osteoblast-like cells (hFOB 1.19) and fibroblast cells (HS-5). After 3 days of the incubation, viability of both types of cells was higher in the case of the nanocomposite than the cells contacted with the pure polylactide. After 7 days of the incubation, metabolic activity of these cells was tested by determination of the concentration of type I collagen. This peptide acted in the experiment as an indicator of the metabolic activity. The level of the collagen produced by hFOB 1.19 cells and HS- 5 cells was higher in the case of the nanocomposite foils than on the pure polymer (Figure 9). These results confirmed the metabolic activity of osteoblasts on the nanocomposite containing hss-SiO${ }_{2}$. It was shown that the nanocomposite surface topography created by the silica nanoparticles was more attractive for fibroblast cells than for osteoblast cells. Production of the collagen assigned to fibroblasts cells was 1.4 times higher than the production of the osteoblast cells.
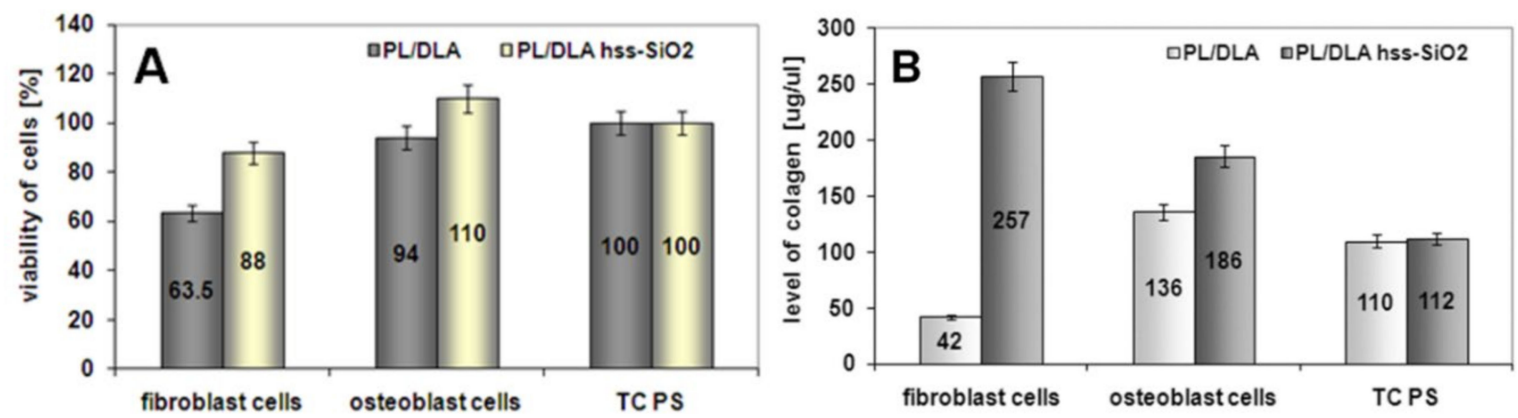

Figure 9. The viability of osteoblast-like cells by hFOB 1.19 cells and fibroblasts HS-5 cells contacted with the nanocomposite materials and the pure polymer foil (A). Level of type-I collagen produced by osteoblast and fibroblast cells (B). TC PS was used as a reference sample.

\section{Discussion}

The possibility of nucleation of apatite on micrometric silica particles and silica gel was tested in laboratories in the 1990s [47,48]. It was shown then that the chemical activity of micrometric particles strongly depends less on the surface chemistry of the microparticle (specifically on the method of its preparation) than on its microstructure (presence of micropores) [47]. It was then suggested that apatite formation in SBF occurs as a result 
of high concentration of surface silanol groups, which may constitute a fordable site for apatite nucleation [49]. Other researchers pointed to the possibility of apatite nucleation through the formation of silanol-phosphate complexes, as it occurs during the formation of a gel layer in bioglass [50]. More importantly, observations made on properly prepared micrometric silica particles can be directly translated into the behaviour of a group of bioactive glasses $[50,51]$. The phenomena known from the nature of micrometric $\mathrm{SiO}_{2}$ particles do not always translate into the behaviour of chemically identical but nanometric silica particles. The analysis of two types of nanometric $\mathrm{SiO}_{2}$ particles differing in their specific surface area showed a synergic effect of surface chemistry and microstructure of the nanoparticle on the maintenance of biological activity (Kokubo test, SBF [52]) both for the particles and for the polymer nanocomposites with their participation. The differences in the specific surface area result from the presence of micropores (i.e., pores of diameter smaller than $2 \mathrm{~nm}$ ) in the hss- $\mathrm{SiO}_{2}$ nanoparticles. Cho and al. suggested that mesopores in the range from 2 to $200 \mathrm{~nm}$ present on the material's surface did not influence nucleation of an apatite layer. On the other hand, micropores smaller than $2 \mathrm{~nm}$ induced the formation of apatite, playing a role of the center of apatite nucleation (similar to a defect in traditional materials) [47].

Nanometric silica with a high specific surface area is additionally characterized by chemical groups typical for the nanoparticles (e.g., for $\mathrm{SiO}_{2}$, the groups are $\mathrm{Si}-\mathrm{O}$ in air and $\mathrm{Si}-\mathrm{OH}$ in water conditions) are exposed on the surface of the nanoparticles (FTIR study, Figure 3). Some Researchers suggested that these bands could be attributed to geminal hydroxyls $\mathrm{Si}-(\mathrm{OH})_{2}[43,44]$. These bands were much more intensive in hss-SiO than in lss-SiO $\mathrm{S}_{2}$. Weak $\mathrm{OH}$ bands in the $3680-3750 \mathrm{~cm}^{-1}$ range can only be captured when using a special powder spectroscopic examination technique such as DRIFTs; other spectroscopic methods are unable to capture such nuances. In this case, it means that the large surface area of hss-SiO 2 (BET, shown in Table 2) adsorbs water from the air very quickly, which causes the appearance of chemically active $\mathrm{OH}$ groups. Probably, the hydroxyl groups are able to generate the second-row interactions between the polymer chain and the hss- $\mathrm{SiO}_{2}$ nanoparticle, hence its bioactivity (the Zeta potential indicating bioactivity of the hss- $\mathrm{SiO}_{2}$ after $48 \mathrm{~h}$ of the incubation in $\mathrm{SBF}-$ Figure 7 ) and higher viability and metabolic activity of mesenchymal cells (Figure 8A,B). Such properties were not present in the lss- $\mathrm{SiO}_{2}$ nanoparticle, which results in lower crystallinity comparable to the pristine polymer (PLDLA), as well as a lack of bioactivity (no nucleation of apatite on the surface, Figure $6 \mathrm{~B}$ ) and lower biological activity is visible in the viability and metabolic activity of the mesenchymal cells (Figure 8A,B). In the case of polymer-ceramic materials, the formation of a nanocomposite is accompanied by various phenomena, which are not present in the case of conventional composite materials. They are caused by the interaction between polymer chains and fine particles introduced into a polymer matrix.

In the case of polymer-ceramic materials, the formation of a nanocomposite is accompanied by various phenomena, which are not present in the case of conventional composite materials. They are caused by the interaction between polymer chains and fine particles introduced into a polymer matrix. Introduction of a filler with numerous active chemical groups into the polymer matrix affects the degree of short-range order (structure) and also its microstructure. $\mathrm{SiO}_{2}$ nanoparticles with smaller specific surface area show stronger tendency for agglomeration, which manifests in a change of surface topography (RMS) of the nanocomposite (surface pores in PLDLA/lss-SiO ${ }_{2}$ ) and decrease of its crystallinity. No changes in the topography of the nanocomposite but also an increase in its crystallinity and a shift of the melting temperature of the material towards lower values in comparison with the pure polymer confirms better compatibility of hss-SiO $\mathrm{S}_{2}$ nanoparticles with PLDLA matrix $[33,53,54]$. The high dispersion degree of $\mathrm{hss}_{-} \mathrm{SiO}_{2}$ nanoparticles induces physicochemical changes in the surface-an increase in hydrophobicity while maintaining the ratio between the polar and dispersion component at the level of the pure polymer. The literature reports examples of materials with similar behaviour, which are caused by the reorganization of the polymer chain through interaction with the nanoparticles $[55,56]$. 
The drying stage of the nanocomposite may be responsible for changes in surface properties; incorrect conditions lead to the process of secondary agglomeration [57]. It seems that such a negative phenomenon of the secondary agglomeration occurred in the case of PLDLA/lss-SiO 2 nanocomposite; a change in wettability, increase in the dispersion component, and at the same time a change in topography confirmed lower compatibility of the filler to the polymer matrix. The usefulness of prepared PLDLA $/ \mathrm{SiO}_{2}$ nanocomposites as potential bone substitute materials was confirmed by a bioactivity test in which apatite forms were observed on the PLDLA/hss-SiO ${ }_{2}$ surface (Figure 6). Based on the literature data, it is possible to predict the chemical activity of e.g., bio-glass by testing the zeta potential in the simulated body fluid. The authors of these papers define the kinetics of the appearance of the Ca-P layer in in vitro conditions and relate it to the bioactive potential in in vivo conditions $[58,59]$.

Using a similar methodology to the studies on the suitability of nanoparticles and nanocomposites with their presence, the time needed to change the zeta potential value from a negative one (typical of the $\mathrm{SiO}_{2}$ gel, $\mathrm{Si}-\mathrm{OH}$ ) to a slightly positive one was determined. In this time, calcium and then phosphate ions responsible for the Ca-P layer and cauliflower-like apatite forms are accumulated $[34,37,60]$. Nanometric silica with a highly developed surface area is bioactive when the zeta potential is close to $0 \mathrm{mV}$. It reaches this value after $72 \mathrm{~h}$, which makes it as chemically active as the Hench bioglass.

Probably part of the silica particles was exposed on the composite surface and their physicochemical properties strongly influenced the bioactivity of the material. It seems that the key factor was the specific surface area of the silica powders. The hss-SiO $\mathrm{S}_{2}$ had higher specific surface area, which was mainly a result of the presence of micropores. It enables to assume that there was more O-Si-O (silane) groups, which were able to form bonds between the material and surroundings, which in turn facilitated crystallisation of apatite [37,61].

Surface properties of a biomaterial are the key factor responsible for their biological response [62,63]. Cell-materials interaction strongly depends on the material's surface properties [28]. Osteoblast cells are very sensitive to many properties of surface such as: roughness, wettability, surface free energy, and its chemical structure [64]. The previous results (structure, wettability, surface free energy, and morphology) presented in this paper showed that nanocomposite materials based on polylactide were characterized by different microstructures and domain-like surfaces in which some areas were modified by the nanofillers particles that interacted with the polymer matrix (PLDLA/lss-SiO 2 ). Biological studies of the nanocomposites in contact with mesenchymal stem cells (MSCs) derived from bone marrow provided promising results. Such cells are more sensitive investigation tools than usually applied cells from the continuous lines [65-67]. The ALP activity was significantly increased in nanocomposites foil PLDLA/hss-SiO ${ }_{2}$ when compared to other nanocomposites foils and polymer-based materials on day 21. Researchers reported that silica-coated nanoparticles stimulate the osteogenic differentiation of bone marrow MSCs in vitro concomitant with the upregulation of ALP activity $[68,69]$. Nanosilica may induce in vitro osteogenic differentiation of precursor cells, as well as improve in vitro osteogenic formation.

\section{Conclusions}

Results indicate that nanometric dispersion of the nano-fillers (hss- $\left.\mathrm{SiO}_{2}, \mathrm{lss}_{-} \mathrm{SiO}_{2}\right)$ in a resorbable matrix of poly(L-lactide-co-D,L-lactide) is a promising route for the preparation of bioactive nanocomposite implants destined for applications in bone surgery. However, properties of silica nanopraticles such as specific surface area, size, zeta potential, and amount of chemical active groups on the surface strongly influence the biological response of cells to the nano-silica filled materials. They include:

- the particles of the high specific surface silica $\left(\mathrm{hss}-\mathrm{SiO}_{2}\right.$ ) in polymer matrix (PLDLA) significantly enhanced the formation of apatite-like structures at the surface during a 
bioactivity test (in vitro conditions); this feature can be monitored by zeta potential in SBF;

- the nanofillers such as hss-SiO ${ }_{2}$ significantly influence physicochemical properties such as wetting contact angle and surface free energy of polymer matrix, and slightly influence the crystallinity of nanocomposite materials (PLDLA/hss- $\mathrm{SiO}_{2}$ ). These parameters may be relevant to the biological response from both the mesenchymal and somatic cells;

- the results of biological investigations, realised with the use of mesenchymal stem cells, show that the bioactive nanocomposite where hss-SiO${ }_{2}$ was used as a filler may stimulate differentiation of mesenchymal cells into osteoblasts-resulting in higher proliferation stage of cells in in vitro conditions and higher alkaline phosphatase activity. Somatic cells: fibroblast and osteoblast contacted with nanocomposite with hss- $\mathrm{SiO}_{2}$ confirm that this material is much more suitable for promotion of cells proliferation than PLDLA/lss-SiO 2 .

The results showed also that the bioactivity of nanocomposite materials can be anticipated by the zeta potential of nanoadditives. This can also be useful in the fabrication of nanocomposites with homogenous dispersion of nanofillers in a polymer matrix. Thorough characterization of nanofillers belonging to the same group of materials i.e., ceramic nanoparticles, may help to design the nanocomposite 3D scaffolds.

Author Contributions: Conceptualization, Ł.Z. and E.S.-Z.; methodology, Ł.Z., A.M.O., A.Ł., A.R., W.N., A.R.-K., E.D. and E.S.-Z.; validation, Ł.Z., A.R.-K. and E.S.-Z.; formal analysis, Ł.Z. and E.S.Z.; investigation, Ł.Z., A.M.O., A.Ł., A.R., W.N., A.R.-K., E.D. and E.S.-Z.; resources, E.S.-Z.; data curation, E.S.-Z.; writing—original draft preparation, Ł.Z. and E.S.-Z.; writing—review and editing, Ł.Z., A.R.-K. and E.S.-Z.; visualization, Ł.Z., E.D. and W.N.; supervision, funding acquisition, E.S.-Z. All authors have read and agreed to the published version of the manuscript.

Funding: This research was funded by scientific project: (Nano)composite hybrid materials with osteoconductive and osteoinductive properties for bone regeneration, grant number N N507 401939.

Institutional Review Board Statement: Not applicable.

Informed Consent Statement: Not applicable.

Data Availability Statement: Not applicable.

Acknowledgments: The investigators were thanks laboratory staff worked in Zoology Institute and Biomedical Biomedical Research of Jagiellonian University for help during the experiment with MScs and Czeslawa Paluszkiwicz for showing new opportunities for speculative research, including DRIFT techniques.

Conflicts of Interest: The authors declare no conflict of interest.

\section{References}

1. Fernandez de Grado, G.; Keller, L.; Idoux-Gillet, Y.; Wagner, Q.; Musset, A.-M.; Benkirane-Jessel, N.; Bornert, F.; Offner, D. Bone substitutes: A review of their characteristics, clinical use, and perspectives for large bone defects management. J. Tissue. Eng. 2018, 9, 2041731418776819. [CrossRef]

2. Faour, O.; Dimitriou, R.; Cousins, C.A.; Giannoudis, P.V. The use of bone graft substitutes in large cancellous voids: Any specific needs? Injury 2011, 42, 87-90. [CrossRef] [PubMed]

3. Campana, V.; Milano, G.; Pagano, E.; Barba, M.; Cicione, C.; Salonna, G.; Lattanzi, W.; Logroscino, G. Bone substitutes in orthopaedic surgery: From basic science to clinical practice. J. Mater. Sci. Mater. Med. 2014, 25, 2445-2461. [CrossRef]

4. Giannoudis, P.V.; Dinopoulos, H.; Tsiridis, E. Bone substitutes: An update. Injury 2005, 36, 20-27. [CrossRef]

5. Wagner, Q.; Offner, D.; Idoux-Gillet, Y.; Saleem, I.; Somavarapu, S.; Schwinté, P.; Benkirane-Jessel, N.; Keller, L. Advanced nanostructured medical device combining mesenchymal cells and VEGF nanoparticles for enhanced engineered tissue vascularization. Nanomed. (Lond.) 2016, 11, 2419-2430. [CrossRef]

6. Schmidt-Bleek, K.; Schell, H.; Schulz, N.; Hoff, P.; Perka, C.; Buttgereit, F.; Volk, H.-D.; Lienau, J.; Duda, G.N. Inflammatory phase of bone healing initiates the regenerative healing cascade. Cell Tissue Res. 2012, 347, 567-573. [CrossRef] [PubMed]

7. Offner, D.; Wagner, Q.; Idoux-Gillet, Y.; Gegout, H.; Ferrandon, A.; Schwinté, P.; Musset, A.-M.; Benkirane-Jessel, N.; Keller, L. Hybrid collagen sponge and stem cells as a new combined scaffold able to induce the re-organization of endothelial cells into clustered networks. Biomed. Mater. Eng. 2017, 28, 185-192. [CrossRef] [PubMed] 
8. Götz, W.; Reichert, C.; Canullo, L.; Jäger, A.; Heinemann, F. Coupling of osteogenesis and angiogenesis in bone substitute healing-A brief overview. Ann. Anat. 2012, 194, 171-173. [CrossRef]

9. Lu, J.X.; Flautre, B.; Anselme, K.; Hardouin, P.; Gallur, A.; Descamps, M.; Thierry, B. Role of interconnections in porous bioceramics on bone recolonization in vitro and in vivo. J. Mater. Sci. Mater. Med. 1999, 10, 111-120. [CrossRef]

10. Glowacki, J. Angiogenesis in fracture repair. Clin. Orthop Relat. Res. 1998, 82-89. [CrossRef]

11. Geiger, F.; Beverungen, M.; Lorenz, H.; Wieland, J.; Fehr, M.; Kasten, P. Bone Substitute Effect on Vascularization and Bone Remodeling after Application of phVEGF165 Transfected BMSC. J. Funct. Biomater. 2012, 3, 313-326. [CrossRef] [PubMed]

12. Le Huec, J.C.; Schaeverbeke, T.; Clement, D.; Faber, J.; Le Rebeller, A. Influence of porosity on the mechanical resistance of hydroxyapatite ceramics under compressive stress. Biomaterials 1995, 16, 113-118. [CrossRef]

13. Yuan, H.; Kurashina, K.; de Bruijn, J.D.; Li, Y.; de Groot, K.; Zhang, X. A preliminary study on osteoinduction of two kinds of calcium phosphate ceramics. Biomaterials 1999, 20, 1799-1806. [CrossRef]

14. Galois, L.; Mainard, D. Bone ingrowth into two porous ceramics with different pore sizes: An experimental study. Acta Orthop. Belg. 2004, 70, 598-603.

15. Roberts, T.T.; Rosenbaum, A.J. Bone grafts, bone substitutes and orthobiologics: The bridge between basic science and clinical advancements in fracture healing. Organogenesis 2012, 8, 114-124. [CrossRef]

16. Kargozar, S.; Montazerian, M.; Fiume, E.; Baino, F. Multiple and Promising Applications of Strontium (Sr)-Containing Bioactive Glasses in Bone Tissue Engineering. Front. Bioeng. Biotechnol. 2019, 7, 161. [CrossRef] [PubMed]

17. O'Donnell, M.D.; Hill, R.G. Influence of strontium and the importance of glass chemistry and structure when designing bioactive glasses for bone regeneration. Acta Biomater. 2010, 6, 2382-2385. [CrossRef] [PubMed]

18. Wu, C.; Zhou, Y.; Lin, C.; Chang, J.; Xiao, Y. Strontium-containing mesoporous bioactive glass scaffolds with improved osteogenic/cementogenic differentiation of periodontal ligament cells for periodontal tissue engineering. Acta Biomater. 2012, 8, 3805-3815. [CrossRef] [PubMed]

19. Li, H.C.; Wang, D.G.; Chen, C.Z. Effect of zinc oxide and zirconia on structure, degradability and in vitro bioactivity of wollastonite. Ceram. Int. 2015, 41, 10160-10169. [CrossRef]

20. Webster, T.J.; Ergun, C.; Doremus, R.H.; Siegel, R.W.; Bizios, R. Enhanced functions of osteoblasts on nanophase ceramics. Biomaterials 2000, 21, 1803-1810. [CrossRef]

21. Hong, Z.; Zhang, P.; He, C.; Qiu, X.; Liu, A.; Chen, L.; Chen, X.; Jing, X. Nano-composite of poly(L-lactide) and surface grafted hydroxyapatite: Mechanical properties and biocompatibility. Biomaterials 2005, 26, 6296-6304. [CrossRef]

22. Carson, J.S.; Bostrom, M.P.G. Synthetic bone scaffolds and fracture repair. Injury 2007, 38, 33-37. [CrossRef]

23. Zhang, P.; Hong, Z.; Yu, T.; Chen, X.; Jing, X. In Vivo mineralization and osteogenesis of nanocomposite scaffold of poly(lactideco-glycolide) and hydroxyapatite surface-grafted with poly(L-lactide). Biomaterials 2009, 30, 58-70. [CrossRef] [PubMed]

24. Kotela, I.; Podporska, J.; Soltysiak, E.; Konsztowicz, K.J.; Blazewicz, M. Polymer nanocomposites for bone tissue substitutes. Ceram. Int. 2009, 35, 2475-2480. [CrossRef]

25. Stodolak, E.; Szumera, M.; Blazewicz, M. Osteoconductive Nanocomposite Materials for Bone Regeneration. Mater. Sci. Forum. 2012, 730-732, 38-43. [CrossRef]

26. Stodolak-Zych, E.; Łuszcz, A.; Menaszek, E.; Ścisłowska-Czarencka, A. Resorbable Polymer Membranes for Medical Applications. J. Biomim. Biomater. Biomed. Eng. 2014, 19, 99-108. [CrossRef]

27. Yan, S.; Yin, J.; Yang, Y.; Dai, Z.; Ma, J.; Chen, X. Surface-grafted silica linked with l-lactic acid oligomer: A novel nanofiller to improve the performance of biodegradable poly(l-lactide). Polymer 2007, 48, 1688-1694. [CrossRef]

28. Lord, M.S.; Cousins, B.G.; Doherty, P.J.; Whitelock, J.M.; Simmons, A.; Williams, R.L.; Milthorpe, B.K. The effect of silica nanoparticulate coatings on serum protein adsorption and cellular response. Biomaterials 2006, 27, 4856-4862. [CrossRef]

29. Vijayalakshmi, D.; Balamurugan, A.; Rajeswari, S. Synthesis and Characterization of Porous Silica Gels for Biomedical Applications. Trends Biomater. Artif. Organs 2005, 18, 101-106.

30. Ballarre, J.; López, A.J.; Cavalieri, A. Nano-indentation of hybrid silica coatings on surgical grade stainless steel. Thin Solid Films 2008, 516, 1082-1087. [CrossRef]

31. Perry, C.C. An overview of silica in biology: Its chemistry and recent technological advances. Prog. Mol. Subcell. Biol. 2009, 47, 295-313. [CrossRef] [PubMed]

32. Niu, L.-N.; Jiao, K.; Ryou, H.; Diogenes, A.; Yiu, C.K.Y.; Mazzoni, A.; Chen, J.-H.; Arola, D.D.; Hargreaves, K.M.; Pashley, D.H.; et al. Biomimetic silicification of demineralized hierarchical collagenous tissues. Biomacromolecules 2013, 14, 1661-1668. [CrossRef] [PubMed]

33. Zhu, A.; Diao, H.; Rong, Q.; Cai, A. Preparation and properties of polylactide-silica nanocomposites. J. Appl. Polym. Sci. 2010, 116, 2866-2873. [CrossRef]

34. Li, P.; Ohtsuki, C.; Kokubo, T.; Nakanishi, K.; Soga, N.; Nakamura, T.; Yamamuro, T. Apatite Formation Induced by Silica Gel in a Simulated Body Fluid. J. Am. Ceram. Soc. 1992, 75, 2094-2097. [CrossRef]

35. Coreño, J.; Rivera, E.; Castaño, V.; Rodríguez, R. Apatite growth on calcium adsorbed surface of wet flocculated silica particles immersed in a modified simulated body fluid. J. Biomed. Mater. Res. 2000, 53, 44-50. [CrossRef]

36. Galli, C.; Collaud Coen, M.; Hauert, R.; Katanaev, V.L.; Gröning, P.; Schlapbach, L. Creation of nanostructures to study the topographical dependency of protein adsorption. Colloids Surf. B 2002, 26, 255-267. [CrossRef] 
37. Lu, H.H.; Pollack, S.R.; Ducheyne, P. Temporal zeta potential variations of $45 \mathrm{~S} 5$ bioactive glass immersed in an electrolyte solution. J. Biomed. Mater. Res. 2000, 51, 80-87. [CrossRef]

38. Kokubo, T.; Kim, H.-M.; Kawashita, M. Novel bioactive materials with different mechanical properties. Biomaterials 2003, 24, 2161-2175. [CrossRef]

39. Rainer, A.; Giannitelli, S.M.; Abbruzzese, F.; Traversa, E.; Licoccia, S.; Trombetta, M. Fabrication of bioactive glass-ceramic foams mimicking human bone portions for regenerative medicine. Acta Biomat. 2008, 4, 362-369. [CrossRef]

40. Kokubo, T.; Takadama, H. How useful is SBF in predicting in vivo bone bioactivity? Biomaterials 2006, 27, 2907-2915. [CrossRef]

41. Robey, P.G.; Termine, J.D. Human bone cellsin vitro. Calcif. Tissue Int. 1985, 37, 453-460. [CrossRef]

42. Sinha, R.K.; Morris, F.; Shah, S.A.; Tuan, R.S. Surface Composition of Orthopaedic Implant Metals Regulates Cell Attachment, Spreading, and Cytoskeletal Organization of Primary Human Osteoblasts In Vitro. Clin. Orthop. Related Res. 1994, 305, $258-272$. [CrossRef]

43. Stodolak, E.; Paluszkiewicz, C.; Bogun, M.; Blazewicz, M. Nanocomposite fibres for medical applications. J. Mol. Struc. 2009, 924-926, 208-213. [CrossRef]

44. Sitarz, M.; Handke, M.; Mozgawa, W. Identification of silicooxygen rings in $\mathrm{SiO}_{2}$ based on IR spectra. Spectrochim. Acta Part. A 2000, 56, 1819-1823. [CrossRef]

45. Xu, T.; Zhang, N.; Nichols, H.; Shi, D.; Wen, X. Modification of nanostructured materials for biomedical applications. J. Mater. Sci. Eng. C. 2007, 27, 579-594. [CrossRef]

46. Beck, G.R.; Ha, S.-W.; Camalier, C.E.; Yamaguchi, M.; Li, Y.; Lee, J.-K.; Weitzmann, M.N. Bioactive silica-based nanoparticles stimulate bone-forming osteoblasts, suppress bone-resorbing osteoclasts, and enhance bone mineral density in vivo. Nanomed. Nanotechnol. Biol. Med. 2012, 8, 793-803. [CrossRef]

47. Cho, S.-B.; Nakanishi, K.; Kokubo, T.; Soga, N.; Ohtsuki, C.; Nakamura, T. Apatite formation on silica gel in simulated body fluid: Its dependence on structures of silica gels prepared in different media. J. Biomed. Mater. Res. 1996, 33, 145-151. [CrossRef]

48. Yamamuro, T.; Hench, L.L.; Wilson, J. Handbook of Bioactive Ceramics; CRC-Press: Oxfordshire, UK, 1990; ISBN 978-0-8493-3241-8.

49. Ohtsuki, C.; Kokubo, T.; Yamamuro, T. Mechanism of apatite formation on CaOSiO2P2O5 glasses in a simulated body fluid. $J$. Non-Cryst. Solids 1992, 143, 84-92. [CrossRef]

50. Andersson, Ö.H.; Karlsson, K.H. On the bioactivity of silicate glass. J. Non-Cryst. Solids 1991, 129, 145-151. [CrossRef]

51. Iler, R.K. Coagulation of colloidal silica by calcium ions, mechanism, and effect of particle size. J. Colloid. Interface Sci. 1975, 53, 476-488. [CrossRef]

52. Kokubo, T. Bioactive glass ceramics: Properties and applications. Biomaterials 1991, 12, 155-163. [CrossRef]

53. Wu, T.-M.; Wu, C.-Y. Biodegradable poly (lactic acid)/chitosan-modified montmorillonite nanocomposites: Preparation and characterization. Polym. Degrad. Stab. 2006, 91, 2198-2204. [CrossRef]

54. Maiti, P.; Yamada, K.; Okamoto, M.; Ueda, K.; Okamoto, K. New Polylactide/Layered Silicate Nanocomposites: Role of Organoclays. Chem. Mater. 2002, 14, 4654-4661. [CrossRef]

55. Moreno, A.J.; Bacova, P.; Verso, F.L.; Arbe, A.; Colmenero, J.; Pomposo, J.A. Effect of chain stiffness on the structure of single-chain polymer nanoparticles. J. Phys. Condens. Matter. 2017, 30, 034001. [CrossRef] [PubMed]

56. Khan, J.; Harton, S.E.; Akcora, P.; Benicewicz, B.C.; Kumar, S.K. Polymer Crystallization in Nanocomposites: Spatial Reorganization of Nanoparticles. Macromolecules 2009, 42, 5741-5744. [CrossRef]

57. Zare, Y. Study of nanoparticles aggregation/agglomeration in polymer particulate nanocomposites by mechanical properties. Compos. Part. A 2016, 84, 158-164. [CrossRef]

58. Hench, L.L. Bioceramics: From Concept to Clinic. J. Am. Ceram. Soc. 1991, 74, 1487-1510. [CrossRef]

59. Ducheyne, P. Bioceramics: Material characteristics versus in vivo behavior. J. Biomed. Mater. Res. 1987, 21, 219-236. [PubMed]

60. Cho, S.B.; Miyaji, F.; Kokubo, T.; Nakanishi, K.; Soga, N.; Nakamura, T. Apatite formation on silica gel in simulated body fluid: Effects of structural modification with solvent-exchange. J. Mater. Sci. Mater. Med. 1998, 9, 279-284. [CrossRef]

61. Coreño, J.; Martínez, A.; Coreño, O.; Bolarín, A.; Sánchez, F. Calcium and phosphate adsorption as initial steps of apatite nucleation on sol-gel-prepared titania surface. J. Biomed. Mat. Res. Part. A 2003, 64, 131-137. [CrossRef]

62. Goddard, J.M.; Hotchkiss, J.H. Polymer surface modification for the attachment of bioactive compounds. Prog. Polym. Sci. 2007, 32, 698-725. [CrossRef]

63. Webster, T.J.; Siegel, R.W.; Bizios, R. Nanoceramic surface roughness enhances osteoblast and osteoclast functions for improved orthopaedic/dental implant efficacy. Scrip. Mater. 2001, 44, 1639-1642. [CrossRef]

64. Hong, Z.; Qiu, X.; Sun, J.; Deng, M.; Chen, X.; Jing, X. Grafting polymerization of l-lactide on the surface of hydroxyapatite nano-crystals. Polymer 2004, 45, 6699-6706. [CrossRef]

65. Gomillion, C.T.; Burg, K.J.L. Stem cells and adipose tissue engineering. Biomaterials 2006, 27, 6052-6063. [CrossRef] [PubMed]

66. Cenni, E.; Ciapetti, G.; Granchi, D.; Arciola, C.R.; Savarino, L.; Stea, S.; Montanaro, L.; Pizzoferrato, A. Established Cell Lines and Primary Cultures in Testing Medical Devices In Vitro. Toxicol. In Vitro 1999, 13, 801-810. [CrossRef]

67. De Boer, J.; Siddappa, R.; Gaspar, C.; van Apeldoorn, A.; Fodde, R.; van Blitterswijk, C. Wnt signaling inhibits osteogenic differentiation of human mesenchymal stem cells. Bone 2004, 34, 818-826. [CrossRef] 
68. Zhou, X.; Feng, W.; Qiu, K.; Chen, L.; Wang, W.; Nie, W.; Mo, X.; He, C. BMP-2 Derived Peptide and Dexamethasone Incorporated Mesoporous Silica Nanoparticles for Enhanced Osteogenic Differentiation of Bone Mesenchymal Stem Cells. ACS Appl. Mater. Interfaces 2015, 7, 15777-15789. [CrossRef] [PubMed]

69. Gandhimathi, C.; Quek, Y.J.; Ezhilarasu, H.; Ramakrishna, S.; Bay, B.-H.; Srinivasan, D.K. Osteogenic Differentiation of Mesenchymal Stem Cells with Silica-Coated Gold Nanoparticles for Bone Tissue Engineering. Int. J. Mol. Sci. 2019, $20,5135$. [CrossRef] 